W W W. TE R A P E V T Y K A. C O M.U A

\title{
ВІДНОВНЕ ЛІКУВАННЯ ТА РЕАБІЛІТАЦІЯ ХВОРИХ ПІСЛЯ ГОСТРОГО КОРОНАРНОГО СИНДРОМУ: НАУКОВІ ДЕТЕРМІНАНТИ І ПРАКТИЧНА РЕАЛІЗАЦІЯ
}

\author{
Р.В. Нестерак, І.П. Вакалюк
}

Івано-Франківський національний медичний університет, м. Івано-Франківськ

Резюме. На сучасному етапі особлива увага спрямована на удосконалення лікування хворих після гострого коронарного синдрому із розробкою індивідуального підходу до відновного лікування та реабілітації. Пошук нових науково обґрунтованих програм базується на комплексному підході з урахуванням медичних, фізичних та психологічних особливостей кожного пацієнта із можливістю реалізації їх як на стаціонарному, так і амбулаторному етапі надання допомоги.

Мета роботи. Проаналізувати ефективність відновного лікування та реабілітації хворих після гострого коронарного синдрому залежно від застосованих методів реваскуляризації та програм відновного лікування.

Матеріали та методи. Проаналізовано динаміку гострого коронарного синдрому в Івано-Франківській області в період 2014-2019 рр., оцінено ефективність застосування розробленої програми відновного лікування у хворим із гострим коронарним синдромом залежно від застосованого методу реваскуляризації та реабілітації. Вивчено динаміку клінічного перебігу, рівні тривоги, якість життя та віддалені наслідки захворювання.

Результати. Аналіз динаміки гострого коронарного синдрому в Івано-Франківській області вказує на стабільний відсоток хворих протягом 2014-2019рр. із зростанням кількості хворих, яким проведено черезшкірні коронарні втручання. Застосування розробленої програми відновного лікування хворих сприяло корекції клінічних, психологічних характеристик хворих, а також підвищенню якості життя, що забезпечує позитивний вплив на віддалені наслідки перебігу захворювання, попереджаючи виникнення раптової коронарної смерті, повторних інфрарктів міокарда та госпіталізацій.

Висновки. Динаміка основних показників здоров'я населення Івано-Франківської області вказує на низку особливостей, що потребує удосконалення надання допомоги хворим на гострий коронарний синдром. Розроблена програма відновного лікування хворих на гострий коронарний синдром 3 елевацією сегмента ST після черезшкірного коронарного втручання характеризується покращенням клінічного перебігу захворювання, зменшенням проявів тривоги та поліпшенням якості життя хворих. Така стратегія забезпечує

УДК: 616.127-005.8 DOI: 10.31793/2709-7404.2021.2-1.5

(C) Р.В. Нестерак, І.П. Вакалюк

Надійшла до редакції 03.03.2021

Адреса для листування (Correspondence): Івано-Франківський національний медичний університет, вул. Галицька, 2, м. Івано-Франківськ, 76018, Україна.E-mail: zdovado@ukr.net 
мультидисциплінарний підхід з урахуванням клінічних, психологічних складових, компонентів ставлення до здоров'я та реалізацію медичної, фрізичної та психологічної складових комплексного підходу щодо надання допомоги таким хворим.

Ключові слова: гострий коронарний синдром, черезшкірне коронарне втручання, якість життя, реабілітація, програма.

\title{
Restorative treatment and rehabilitation of patients after acute coronary syndrome: scientific determinants and practical implementation
}

\author{
R.V. Nesterak, I.P. Vakalyuk \\ Ivano-Frankivsk National Medical University, Ivano-Frankivsk
}

\begin{abstract}
At the present stage, special attention is paid to the improvement of the treatment of patients after acute coronary syndrome with the development of an individual approach to the restorative treatment and rehabilitation. The search for new science-based programs is based on a comprehensive approach, taking into account the medical, physical and psychological peculiarities of each patient with the possibility of their implementation both in-patient and outpatient care.
\end{abstract}

The aim of the work. To analyze the effectiveness of restorative treatment and rehabilitation of patients after acute coronary syndrome, depending on the applied methods of revascularization and restorative treatment programs.

Materials and methods. The dynamics of acute coronary syndrome in Ivano-Frankivsk region in the period between 2014-2019 was analyzed, the effectiveness of the developed rehabilitation program in patients with ACS depending on the applied method of revascularization and rehabilitation was evaluated. The dynamics of the clinical course, levels of anxiety, quality of life and long-term consequences of the disease have been studied.

Results. Analysis of the dynamics of acute coronary syndrome in Ivano-Frankivsk region indicates a stable percentage of patients during 2014-2019, with an increase in the number of patients who have been performed percutaneous coronary interventions. The application of the developed program of restorative treatment of patients contributed to the correction of clinical and psychological characteristics of patients, as well as the improvement of the quality of life, which provides a positive impact on long-term consequences of the disease, preventing sudden coronary death occurrence, recurrent myocardial infarction and hospitalization. A clinicalorganizational model of the performance of rehabilitation and restorative treatment in patients with acute coronary syndrome has been developed.

Conclusions. The dynamics of the main indices of health of the Ivano-Frankivsk region's population indicates a number of peculiarities, that necessitates to improve care for patients with acute coronary syndrome. The developed program of restorative treatment of patients with acute coronary syndrome with the elevation of ST segment after percutaneous coronary intervention is characterized by the improved clinical course of the disease, reduction of anxiety and improvement of patients' life quality. This strategy provides a multidisciplinary approach taking into account the clinical, psychological elements, components of health attitude, and it implements the medical, physical and psychological components of a comprehensive approach regarding care for such patients.

Keywords: acute coronary syndrome, percutaneous coronary intervention, restorative treatment, rehabilitation, program.

Пріоритетним завданням медичної галузі $€$ забезпечення відповідного стану здоров'я населення працездатного віку, а при виникненні захворювання максимальне відновлення трудового потенціалу пацієнта [1].
Саме тому реабілітація та відновне лікування є важливими напрямками сучасної медицини.

Кардіологічна реабілітація проходила довгий шлях становлення. В Україні Н.А. Гватуа та 
I.К. Следзевська започаткували кардіореанімаційну і кардіореабілітаційну допомогу хворим із гострим інфрарктом міокарда (IM) та після перенесеного IM [2].

На Прикарпатті реабілітація кардіологічних пацієнтів проводиться вже понад 33 роки. Однак за вимогою часу та в умовах удосконалення діагностики й лікування кардіологічних хворих необхідною умовою $є$ розробка та впровадження сучасних і дієвих методів відновного лікування. На сьогодні розроблені та впроваджені відповідні протоколи, програми та методичні рекомендації щодо реабілітації пацієнтів різного кардіологічного профрілю [3, 4].

На сучасному етапі комплексна реабілітація також $є$ важливим економічно ефективним втручанням для забезпечення сприятливих результатів для широкого спектра серцево-судинних захворювань (ССЗ), зниження серцево-судинної смертності, захворюваності та інвалідності, а також підвищення якості життя та обов'язковою як у стаціонарі, так і амбулаторних умовах. Встановлено складність підбору та розробки індивідуальних програм, яка залежить від неоднорідності пацієнтів як щодо клінічних станів, так і можливості застосування відповідних компонентів. Окремої уваги заслуговує організаційна складова із створенням центрів для забезпечення комплексної, доступної реабілітації на усіх етапах та для усіх хворих із різними проявами СС3 [5].

Основними елементами комплексної кардіологічної реабілітації є: багатоетапність, безперервність та тривалість реабілітації із застосуванням індивідуального підходу з урахуванням медичних, фізичних, психологічних, суспільних, сімейних та професійних потреб [6, 7].

Кардіореабілітація має проводитись реабілітаційною групою із залученням лікарів-кардіологів, інтервенційних кардіологів, лікарів фрізичної та реабілітаційної медицини, фрізичних терапевтів, ерготерапевтів, психологів, психотерапевтів, медичних сестер із реабілітації, асистентів фрізичних терапевтів та ерготерапевтів, соціальних працівників. Команда різнопрофільних спеціалістів має більші можливості для розробки та впровадження більш ефективної персоніфікованої програми реабілітації $[5,6]$.

Мета роботи. Проаналізувати есективність відновного лікування й реабілітації хворих після гострого коронарного синдрому залежно від застосованих методів реваскуляризації та програм відновного лікування.

\section{Матеріали та методи}

На першому етапі дослідження було проаналізовано особливості перебігу та лікування гострого коронарного синдрому в період 2014-2019 рр. в Івано-Франківській області. На другому етапі проаналізовано ефективність застосування розробленої програми відновного лікування у хворих на гострий коронарний синдром (ГКС) з елевацією сегмента ST, група хворих, яким проведена тромболітична терапія (ТЛТ) та черезшкірне коронарне втручання (ЧКВ) (57 хворих), і група хворих із застосуванням інвазивної тактики (78 хворих). Залежно від застосованих методів відновного лікування й реабілітації в кожній виділено: група хворих із застосуванням стандартного лікування, а саме медичної реабілітації, фрізичної реабілітації, яка включала дихальну та лікувальну гімнастику, дозовану ходьбу; група хворих, у яких, поряд із стандартним лікуванням, застосовано сугестивну терапію з музичним супроводом; група хворих, у яких, поряд із стандартним лікуванням, застосовано сугестивну терапію та розроблену програму відновного лікування - авторську програму клініко-психологічної реабілітації кардіологічних хворих шляхом оптимізації внутрішньої картини здоров'я (свідоцтво про реєстрацію авторського права на твір № 75681 від 29.12.2017) [8].

Усім пацієнтам проводили оцінку клінічного перебігу захворювання - анкетування за допомогою українських версій опитувальників: «Шкала оцінки рівня реактивної (ситуативної) та особистісної тривожності» Спілбергера - Ханіна; SAQ - Сіетлський опитувальник (Seattle Angina Questionnaire).

Усі хворі отримували стандартну терапію відповідно до рекомендацій. Сугестивна терапія полягала в застосуванні автосугестії (автотренінгу) за розробленим авторським текстом із музичним супроводом. Музичний супровід складався з трьох композицій. Заняття проводились щодня (кількість - до 20 разів), у палатах стаціонарного відділення за участі від 3 до 9 чоловік, тривалість заняття - 25 хвилин.

Розроблена програма відновного лікування полягала в поєднанні стандартного лікування, сугестивної терапії та програми клініко-психологічної реабілітації кардіологічних хворих шляхом оптимізації внутрішньої картини здоров'я (ВКЗ). Процедура участі пацієнтів у програмі відбувалась за такими кроками: 1) вступна бесіда, з'ясування мотивації участі в програмі; 2) робота в обраній програмі 
оптимізації BK3 (5 занять по 60 хвилин) та індивідуальне психологічне консультування (60 хвилин) на запит окремих досліджуваних; 3) постдіагностичний етап результатів впливу програми (відбувається через 1 місяць, 6 місяців після закінчення програми). Заняття побудовані з урахуванням компонентів BK3, кожний компонент (сенситивний, емоційний, когнітивний, поведінковий, ціннісно-мотиваційний) розглядався на окремому занятті [9]

Отримані результати були статистично оброблені методами варіаційної статистики (середне арифметичне, стандартна помилка, середнє квадратичне відхилення, довірчий інтервал). Вірогідність відмінностей між порівнюваними групами визначали за допомогою t-тесту Стьюдента. Статистичну обробку отриманих результатів проведено за допомогою комп'ютерної програми IBM SPSS (Statistical Package for the Social Sciences) Statistics 23, пакета статистичних функцій програми Microsoft Excel. Ведення банку даних дослідження, основні обчислення похідних показників, частотні

\section{Рисунок 1}

Динаміка кількості ГКС в Івано-Франківській області

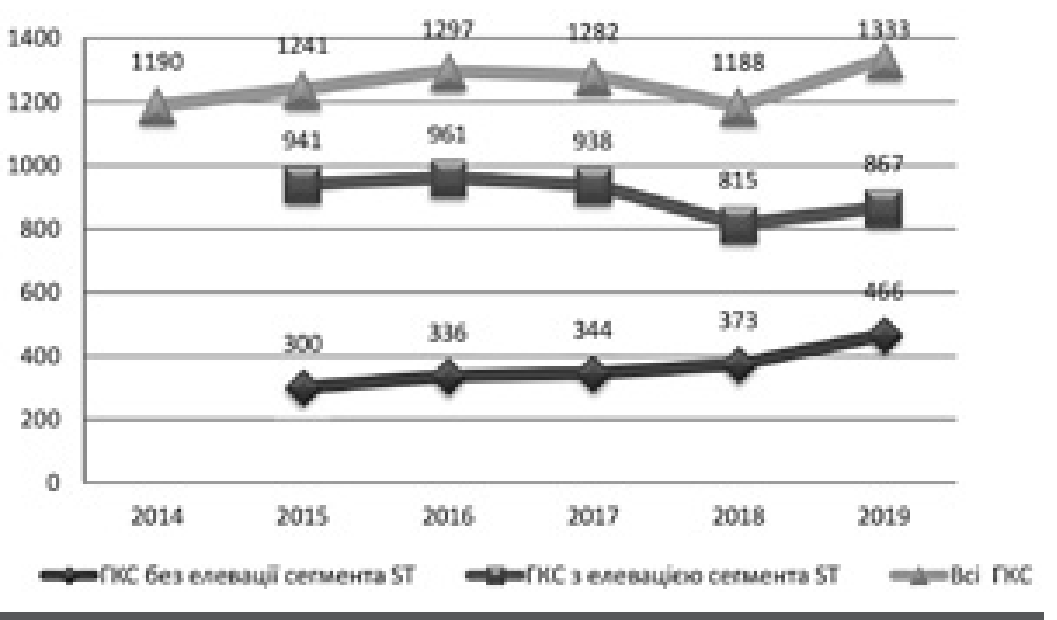

\section{Рисунок 2}

Кількість проведених реваскуляризацій із приводу ГКС упродовж 20142019 pp.

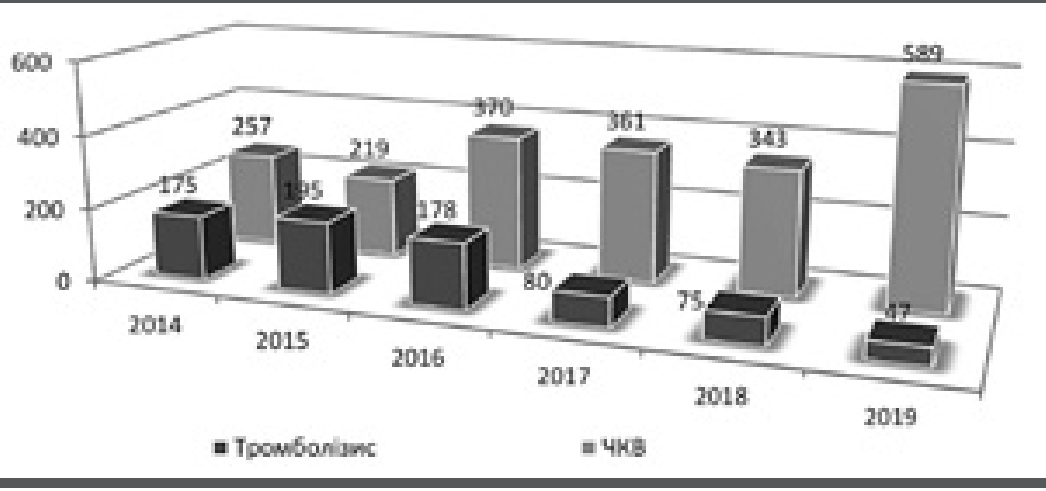

характеристики знаків, побудову діаграм виконували програмним забезпеченням Microsoft Access, Microsoft Excel 2010 (номер ліцензії 01631-551-3027986-27852).

\section{Результати та обговорення}

Проаналізувавши основні показники стану здоров'я населення Івано-Франківської області, встановлено, що важливою медико-соціальною проблемою є хвороби системи кровообігу: атеросклероз, ішемічна хвороба серця, артеріальна гіпертензія та їх ускладнення, які посідають перше місце серед інших нозологій.

В області в період 2014-2019 рр. спостерігається коливання кількості випадків інфаркту міокарда. Найвищим цей показник був у 2019 році - 1333 випадки, а у 2014 та 2018 роках він був найменшим — 1190 та 1188 випадків відповідно. Кількість випадків ГКС з елевацією сегмента ST була найвищою у 2016 році - 961, ГKC без елевації сегмента ST - 373, загалом не відмічається значних коливань у відсотковому співвідношенні. Зокрема, ГКС з елевацією сегмента ST у 2016 році становив 962 (74,1\%) випадки, а у 2018 році - 815 (68,6\%) випадків. ГКС без елевації сегмента ST у 2016 році становив 336 (25,9\%) випадків, а у 2018 році $373(31,4 \%)$ випадки (див. рис. 1).

у зв'язку з активним впровадженням інтервенційних втручань в Івано-Франківській області, з 2015 року відмічається зростання відсотка хворих, яким проведено ЧКВ. Так, у 2015 році ЧКВ проведено у 219 хворих із ГКС, у 2019 році - у 589 хворих. У зв'язку із географічними особливостями та віддаленістю деяких районів від центрів із можливістю проведення ЧКВ, у частини хворих застосовувалась ТЛТ — у 2015 році було проведено 195 проти 47 у 2019 році (рис. 2).

Враховуючи географічні особливості області, а також недостатню кількість центрів із можливістю проведення ЧКВ, 343 пацієнти з ГКС у 2018 році надійшли до єдиного центру Івано-Франківської області: до 2 год $66(21 \%)$ хворих, 2-6 год - 162 (51\%) хворих, 7-24 год - 19 (6\%) хворих, понад 24 год 19 (6\%) хворих. Більше ніж 68,0\% хворих надійшли в період понад 24 години до відділення без можливості проведення перкутанних втручань. Аналізуючи кількість проведених стентувань по районах області, встановлено зростання кількості втручання в динаміці від 2014 до 2019 року. 
Таким чином, із метою покращення надання медичної допомоги доцільно створити центри із можливістю проведення інвазивних методів діагностики, лікування та реабілітації хворих із визначенням оптимальних регіонів обслуговування.

Нами було проаналізовано ефективність застосування розробленої програми відновного лікування у хворих на ГКС з елевацією сегмента ST при застосування ТЛТ та ЧКВ.

Аналізуючи перебіг ГКС з елевацією сегмента ST у хворих, яким була надана інвазивна тактика лікування, вдалось відмітити покращення клінічної симптоматики захворювання. Застосування сугестивної терапії та розробленої програми сприяло зменшенню нападів стенокардії (на початку лікування напади стенокардії спостерігались у 84,0\% хворих у групі застосування сугестивної терапії та у 80,0\% при застосуванні реабілітації з оптимізацією ВКЗ, а через 6 міс. ангінальний біль відмічали 4,0\% хворих). Задишку, яку відзначали на початку лікування 61,5, 46,1 і 50,0\% хворих відповідно, вже через 1 міс. вдалось зменшити в половини осіб $(38,5,23,08$ і 23,08\%), а через 6 міс. лікування констатувати в третини хворих $(34,6 \%)$ при стандартному лікуванні, у 15,8\% — при застосуванні сугестивної терапії і в 11,5\% — при застосуванні програми відновного лікування. Подібною була динаміка і інших ознак, таких як перебої в роботі серця, серцебиття. Однак швидка втомлюваність та загальна слабкість були досить стійкими, залишались через 1 міс. у майже половини $(46,2$ і $57,7 \%)$ хворих групи стандартного лікування, у третини хворих при використанні сугестивної терапії (34,6 і 38,5\%) і розробленої програми (30,8 і 38,5\%).

Аналізуючи динаміку тривожності в цих групах хворих, встановлено менш значущу динаміку рівнів особистісної тривожності $(p>0,05)$ у групі стандартного лікування та сугестивної терапії, проте через 6 місяців особистісна тривожність зменшувалась у групі застосування програми відновного лікування $3(48,2 \pm 1,19)$ бала на початку лікування до $(36,2 \pm 1,1)$ бала через 6 міс. спостереження $(p<0,05)$.

Оцінюючи якість життя за опитувальником $S A Q$, встановлено покращення за більшістю показників, зокрема збільшення фізичних навантажень, зменшення нападів стенокардії, зростання задоволення лікуванням та ставленням до хвороби (табл.).

Застосування програми відновного лікування сприяло зменшенню випадків повторного інфаркту міокарда, нестабільної стенокардії, повторних госпіталізацій, потреби в проведенні планових та ургентних ЧКВ упродовж трьох років.

Аналізуючи клінічний перебіг у хворих на ГKС з елевацією сегмента ST із застосуванням ТЛТ та ЧКВ, встановлено зменшення нападів стенокардії, задишки і серцебиття у всіх групах хворих починаючи з першого тижня лікування із позитивним клінічним ефектом через 1 і 6 міс. терапії. У групі хворих із програмою відновного лікування через 6 міс. вказані клінічні ознаки відмічали лише поодинокі хворі. Однак у групі стандартного лікування більшість клінічних ознак зменшилась у третини хворих, а саме задишка, яка на початку лікування була в $57,8 \%$, через 6 міс. мала місце в 31,5\% хворих; у групі 3 програмою відновного лікування відсоток таких хворих становив відповідно 52,6 і 10,5\%.

Слід відзначити, що проведення ТЛТ і ЧКВ у більшості хворих зменшувало наявність нападів стенокардії незалежно від проведеного лікування.

\section{Таблиця}

Показники оцінки якості життя за SAQ у хворих на ГKC з елевацією сегмента ST, яким надана інвазивна тактика лікування

\begin{tabular}{|c|c|c|c|c|c|c|}
\hline \multirow[t]{2}{*}{ Показник, бал } & \multicolumn{2}{|c|}{$\begin{array}{l}\text { Стандартне лікування } \\
(\mathrm{n}=26)\end{array}$} & \multicolumn{2}{|c|}{$\begin{array}{l}\text { Сугестивна терапія } \\
(\mathrm{n}=26)\end{array}$} & \multicolumn{2}{|c|}{$\begin{array}{l}\text { Програма відновного } \\
\text { лікування }(\mathrm{n}=26)\end{array}$} \\
\hline & $\begin{array}{l}\text { На початку } \\
\text { лікування }\end{array}$ & 6 місяців & $\begin{array}{l}\text { На початку } \\
\text { лікування }\end{array}$ & 6 місяців & $\begin{array}{l}\text { На початку } \\
\text { лікування }\end{array}$ & 6 місяців \\
\hline Обмеження фізичних навантажень & $42,1 \pm 5,4$ & $60,6 \pm 4,1^{*}$ & $44,6 \pm 4,3$ & $62,7 \pm 5^{\star}$ & $43,1 \pm 4,7$ & $65,5 \pm 5,2^{*}$ \\
\hline Стабільність нападів & $43,2 \pm 8,6$ & $79,5 \pm 7,2^{*}$ & $42,5 \pm 7,4$ & $80,5 \pm 8^{*}$ & $44,6 \pm 8,2$ & $81,2 \pm 8,1^{*}$ \\
\hline Частота нападів & $36,1 \pm 6,7$ & $74,3 \pm 6,3^{*}$ & $37,3 \pm 6,6$ & $75,3 \pm 5^{\star}$ & $37,5 \pm 6,3$ & $76,6 \pm 6,3^{*}$ \\
\hline Задоволення лікуванням & $60,3 \pm 3,5$ & $80,1 \pm 3,5$ & $76,2 \pm 3,2$ & $88,6 \pm 4$ & $77,7 \pm 4,2$ & $91,3 \pm 3,6$ \\
\hline Ставлення до хвороби & $47,2 \pm 4,2$ & $54,2 \pm 4,1$ & $47,1 \pm 4,3$ & $70,1 \pm 5,1^{* *}$ & $45,7 \pm 5,3$ & $90,5 \pm 5,1^{* *}$ \\
\hline
\end{tabular}

Примітка. Достовірність різниці показників порівняно з величинами на початку лікування: * $<<0,05 ;{ }^{*}-<0,01$. 
Ступінь реактивної тривожності поступово знижувався починаючи 31 міс. застосування програми відновного лікування $(p<0,05) 3$ подальшим зниженням на 6-му міс. $(p<0,01)$. У групі хворих сугестивної терапії достовірне $(p<0,05)$ її зниження відмічено лише через 6 міс. лікування, а при застосуванні стандартного лікування спостерігали лише тенденцію до такої динаміки. Особистісна тривожність була більш стійкою, і достовірного зниження $(p<0,05)$ вдалось отримати лише в групі хворих із застосуванням програми відновного лікування лише через 6 міс. після ГКС.

Найбільш суттєвої динаміки цих показників якості життя вдалось отримати саме за показником ставлення до хвороби. Так, якщо на початку лікування він становив $(47,1 \pm 5,2)$ бала, то через 6 міс. - $(87,3 \pm 4,4)$ бала при застосуванні розробленої програми відновного лікування $(p<0,01)$.

Таким чином, оцінка якості життя дозволяє забезпечити індивідуальний підхід у реабілітації до кожного пацієнта з урахуванням анамнезу, клінічного, фрізичного та психологічного стану, застосованих методів реваскуляризаційних втручань та відновного лікування на усіх етапах реабілітації.

\section{Висновки}

На підставі наведеного вище можна зробити такі висновки:

1. Аналіз основних показників здоров'я населення Івано-Франківської області вказує на низку географічних особливостей, що потребує удосконалення надання допомоги хворим на гострий коронарний синдром із розробкою та впровадженням моделей і маршрутів для своєчасного проведення реваскуляризаційних процедур.

2. Ефективність програми реабілітації та відновного лікування у хворих на гострий коронарний синдром з елевацією сегмента ST після черезшкірного коронарного втручання характеризується суттєвою корекцією клінічного перебігу захворювання, зменшенням проявів тривоги та покращенням якості життя хворих.

3. Створена клініко-організаційна модель проведення реабілітації у хворих на гострий коронарний синдром із застосуванням реваскуляризаційних процедур забезпечує мультидисциплінарний підхід з урахуванням клінічних, психологічних складових, компонентів ставлення до здоров'я та реалізацію медичної, фрізичної та психологічної складових комплексного підходу щодо надання допомоги таким хворим.

\section{Список використаної літератури}

1. Коваленко В.М., Корнацький В.М. Стан здоров'я народу України та медичної допомоги третинного рівня. - К.: СПД ФО «Коломіцин В.Ю.», 2019. - 222 c

2. Шумаков В.О., Малиновська І.Е., Бабій Л.М., Терещенко Н.М. Реабілітація пацієнтів із серцево-судинними захворюваннями: історичні віхи, сучасні підходи, місце в клінічній практиці та виклики // Український кардіологічний журнал. — 2019. - № 4. - С. 44-55.

3. Клінічний локальний протокол медичної допомоги: Реабілітація пацієнтів з гострим інорарктом міокарда в стаціонарі кардіодиспансеру. Обгрунтування методології кардіореабілітації. — Івано-Франківськ, 2014

4. Нестерак Р.В., Вакалюк І.П., Середюк Н.М. та ін. Реабілітація та відновне лікування пацієнтів із серцево-судинними захворюваннями. Кардіореабілітація хворих з гострим коронарним синдромом. Методичні рекомендації. — Івано-Франківськ, 2020. — 44 с.

5. Ambrosetti M., Abreu A., Corr U., et al. Secondary prevention through comprehensive cardiovascular rehabilitation: From knowledge to implementation. 2020 update. A position paper from the Secondary Prevention and Rehabilitation Section of the European Association of Preventive Cardiology // European Journal of Preventive Cardiology. - 2020. - Vol. 0 (0). — P. 1-42.

6. Abreu A., Frederix I., Dendale P., et al. Standardization and quality improvement of secondary prevention through cardiac rehabilitation programmes in Europe: The avenue towards an EAPC/ESC accreditation program: A position statement of Secondary Prevention and Cardiac Rehabilitation Section of the European Association of Preventive Cardiology (EAPC) // Eur. J. Prev. Cardiol. — 2020.

7. Швед М.І., Левицька Л.В. Сучасні технології відновного лікування хворих із гострим коронарним синдромом. - К.: Медкнига, 2018. $175 \mathrm{c}$.

8. Нестерак Р.В., Гасюк М.Б., Вакалюк І.П. Програма психологічної реабілітації кардіологічних хворих шляхом оптимізації внутрішньої картини здоров'я. Авторське право на науковий твір (свідоцтво про реєстрацію авторського права на твір № 75681 від 29.12.2017).

9. Вакалюк І.П., Вірстюк Н.Г., Нестерак Р.В. Програма клініко-психологічної реабілітації кардіологічних хворих шляхом оптимізації внутрішньої картини здоров'я. Методичні рекомендації. - 2018. 